\title{
Tissue microarray technology and collagen evaluation to analyze surgical trauma performed with usual blade or ultrasonic harmonic scalpels in rats ${ }^{1}$
}

Octavio Antonio Azevedo da Costa-Filho', Mario Augusto Cray da Costa", Ana Maria Waaga-Gasser'I', Luiz Fernando Kubrusly'v, Luciane Bugmann Moreira de Oliveirav, Luiz Martins Collaçovı, Maria Angélica Baron Magalhães ${ }^{\mathrm{VII}}$, Martin Gasser ${ }^{\mathrm{VIII}}$, Osvaldo Malafaia'X, Jurandir Marcondes Ribas-Filho ${ }^{\mathrm{X}}$

'Fellow PhD degree, Postgraduate Program in Principles of Surgery, Faculdade Evangélica do Paraná (FEPAR) CuritibaPR, Brazil. Intellectual, scientific, conception and design of the study; acquisition, analysis and interpretation of data; technical procedures; statistical analysis; manuscript preparation.

"PhD, Associate Professor, Department of Medicine, Universidade Estadual de Ponta Grossa (UEPG), Brazil. Acquisition, analysis and interpretation of data; statistical analysis.

"'PhD, Transplantation Research Center, Brigham and Women's Hospital, Harvard Medical School, Boston, USA. Intellectual, scientific, conception and design of the study.

IVPhD, Associate Professor, Postgraduate Program in Principles of Surgery, FEPAR, Curitiba-PR, Brazil. Intellectual, scientific, conception and design of the study.

${ }^{\vee} \mathrm{PhD}$, Assistant Professor, Postgraduate Program in Principles of Surgery, FEPAR, Curitiba-PR, Brazil. Acquisition, analysis and interpretation of data; statistical analysis.

${ }^{V I P h D, ~ A s s o c i a t e ~ P r o f e s s o r, ~ P o s t g r a d u a t e ~ P r o g r a m ~ i n ~ P r i n c i p l e s ~ o f ~ S u r g e r y, ~ F E P A R, ~ C u r i t i b a-P R, ~ B r a z i l . ~ A c q u i s i t i o n, ~ a n a l y s i s ~}$ and interpretation of data.

VIIPhD, Assistant Professor, Postgraduate Program in Principles of Surgery, FEPAR, Curitiba-PR, Brazil. Technical procedures, statistical analysis, manuscript writing.

VIIIPhD, Department of Surgery I, University of Wuerzburg, Wuerzburg, Germany. Intellectual, scientific, conception and design of the study.

IXPhD, Full Professor, Postgraduate Program in Principles of Surgery, FEPAR, Curitiba-PR, Brazil. Intellectual, scientific, conception and design of the study; manuscript writing; final approval.

${ }^{x}$ PhD, Associate Professor, Postgraduate Program in Principles of Surgery, FEPAR, Curitiba-PR, Brazil. Intellectual, scientific, conception and design of the study; manuscript writing; final approval.

\section{Abstract}

Purpose: To compare wound healing performed with cold blade (CSB) and ultrasonic harmonic scalpel (UHS) in the abdominal aponeurosis of rats.

Methods: Eighty Wistar rats divided into two groups and underwent midline incision in the linea alba with cold blade and harmonic ultrasonic scalpel. Analysis were performed in subgroups of 10 animals after 3, 7, 14 and 21 days. Macroscopically was observed the presence of hematoma, infection, wound dehiscence, fistula and adherences. Microscopically were used collagen and immunohistochemical staining methods.

Results: Macroscopic, complications showed no statistical difference. Immunohistochemical analysis for MMP-9 was more intense in UHS group $(p<0.05)$. TGF $\beta$ presented its lower expression in UHS group at 14 and 21 days, with no statistical difference at 3 and 7 days $(p<0.05)$. $\alpha$-AML expression appeared higher in UHS group after 14 days and remained similar in others $(p<0.05)$. Collagen deposition had no change in type I, and increased in type III in UHS; at 7th day the deposition was higher in CSB group; at 14 th was similar in both groups $(p<0.001)$.

Conclusion: UHS compared to the CSB has higher lesion area at the time of the incision; as well as it led to the delay of regeneration and scar maturation process.

Key words: Wound Healing. Aponeurosis. Ultrasonics. Rats. 


\section{Introdution}

Incision and hemostasis procedures are performed with different devices in order to provide effective hemostasis and surgical time reduction, without prejudice to tissue healing.

The cold blade scalpel (CBS) is the most widely used instrument for dieresis; it is easy to handle and has predictable tissue damage, but incision bleeding interferes with operative field visibility requiring hemostasis.

Since the introduction of electrocautery by Bovie ${ }^{1}$ several models were developed. The ultrasonic harmonic scalpel (UHS) was initially used in laparoscopic surgery in 1995. With it were introduced new features, like no smoke, good cut, coagulation as monopolar scalpel, dissection with minimal tissue injury, almost no waste, without tissue carbonization and with no electric current transmition to the patient's body. It is being used in both open and endoscopic operations ${ }^{2}$.

The UHS perform hemostasis by combining dissection with blood clotting and consequent obstruction of the vessel. The ultrasound acts as a source of energy through the instrument tip (blade) causing unidirectional vibrations of ultra-high frequencies (300-3000 MHz), which leads to tissue dissection and, at the same time, to blood coagulation. When the blade vibrates at $55.500 \mathrm{~Hz}$ frequency, the sound is converted into mechanical vibratory energy, and acts to promote cutting and coagulation. It provides better coagulation because its blade is blunt and therefore generates slow cutting. The ultrasonic energy allows to cut and coagulate at the precise point of impact with minimal surrounding tissue thermal damage. It also offers great precision in small spaces and good visibility in the surgical field due to minimal smoke production.

Tissue heating caused by UHS has minimum depth compared to laser, radiofrequency and electrocautery, with reduced tissue damage.

This study aims to compare the healing process of incisions made with cold blade and ultrasonic harmonic scalpels in the abdominal wall of rats.

\section{- Methods}

This study was conducted at the Institute of Medical Research, Postgraduate Program in Principles of Surgery, Faculdade Evangélica do Paraná, and was approved by the Research Ethics Committee of the Beneficent Evangelical Society of Curitiba.

Were used 80 rats (Rattus norvegicus albinus, Rodentia mammalia) Wistar male adult with three months old and weighing 250-300 g. They were divided into two groups of 40 . The first had aponeurotic incision in the midline (linea alba) with cold blade scalpel, and the second with ultrasonic harmonic scalpel. The surgical skin incision in all animals was done using cold blade. Each group was subdivided into four subgroups of 10 , with programmed euthanasia in 3, 7, 14 and 21 days.

The cold scalpel consisted of mobile cable ${ }^{\circ} 3$ and blade 15 . The ultrasonic generator model was 300 GEN04 and Ultracision model CS-14C (Ethicon EndoSurgery', Inc).

The animals were kept in a vivarium in circadian light conditions (12/12 h) with stable temperature without noise and housed in standard cages, covered with sawdust and fed by ration for the species, free water and subjected to preoperative fasting for $12 \mathrm{~h}$. Anesthesia was performed with $10 \%$ ketamine hydrochloride and xylazine $2 \%$ in the usual standard for the species.

After anesthesia the animals were positioned supine being fixed by the ends on the operating table; were submitted to ventral wall tricotomy, antisepsis with iodopolipovidone $10 \%$ and covered by surgical 
dressing delimiting the operative area.

The surgical procedure was initiated by incision with cold scalpel with digital hemostasis in all 80 animals, and exposure of the linea alba with $7 \mathrm{~cm}$ long. Next, the first 40 animals group had aponeurosis section made until peritoneum with cold scalpel blade, $6 \mathrm{~cm}$ in length, and the same procedure was done using ultrasonic harmonic scalpel on level 3 (Figure $1 \mathrm{~A}$ ) in the second 40 animals group.

The aponeurosis synthesis was performed with polypropylene continuous sutures in both groups (Figure 1B) and skin's with 5-0 monofilament nylon.
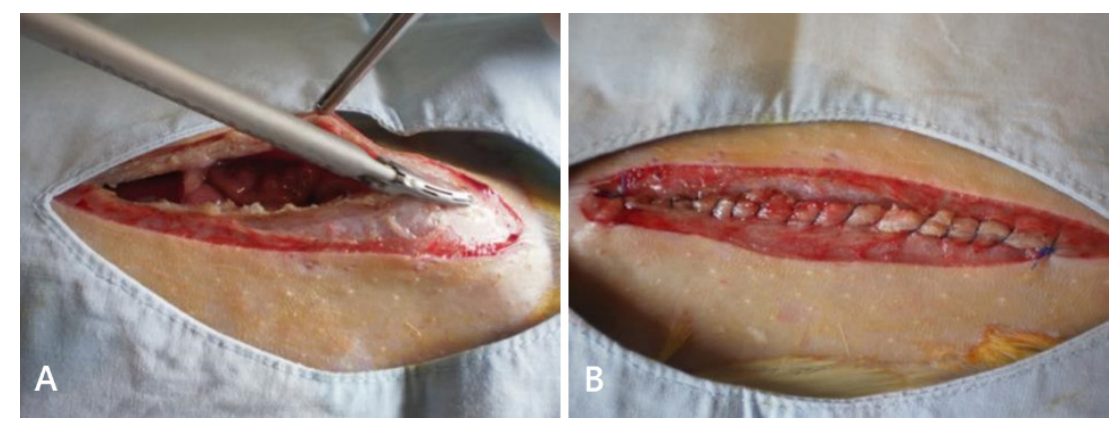

Figure 1 - Incision (A) with ultrasonic harmonic scalpel in the linea alba and continuous suture (B) for closing.

The animals returned to their preoperative housing and diet, having the procedure date and scalpel type used in the operation marked, and also marked the day proposed for euthanasia. They underwent postoperative analgesia with paracetamol 200 $\mathrm{mg} / \mathrm{ml}$ oral dose containing 40 drops for each $50 \mathrm{ml}$ of water in the first two days.

The macroscopic evaluation was daily, with observation of the surgical wound. According to the schedule the rats were submitted to euthanasia by intraperitoneal injection of anesthetic using lethal dose - twice the conventional - at the $3^{\text {rd }}, 7^{\text {th }}, 14^{\text {th }}$ and $21^{\text {st }}$ days after surgery. After death, the abdominal wall was analyzed for the appearance of the scar, presence of hematoma, infection, wound dehiscence (incisional hernia). Soon after, was performed incision in the skin and subcutaneous tissue in craniocaudal direction, section of the entire ventral wall $(8 \mathrm{~cm}$ long and $6 \mathrm{~cm}$ wide) encompassing the entire incision and analyzing presence or absence of hematoma, abscesses, fistulas, dehiscences and adhesions.

\section{Macroscopic healing evaluation}

Was conducted macroscopic evaluation of the wounds considering presence or absence of the following parameters: hematoma, infection, wound dehiscence, fistula and adhesions. Regarding the adhesions, was used the parameters of Goncalves et al. ${ }^{3}$, which classifies them in relation to the intensity (Chart 1).

Chart 1 - Classification of abdominal adhesions ${ }^{12}$.

\begin{tabular}{|c|l|}
\hline Intensity & \multicolumn{1}{c|}{ Parameters } \\
\hline 0 & Complete absence of adhesions \\
\hline 1 & Adhesion of the greater omentum to the surgical wound \\
\hline 2 & Adhesion of the greater omentum and small intestine to wound \\
\hline 3 & Multiple intracavitary adhesions \\
\hline
\end{tabular}




\section{Microscopic evaluation of the healing}

\section{Immunohistochemistry method}

Tissue microarray technique was used (Tissue microarray-TMA) in the center of the scar in standard marked point to paraffin blocks (donor block), and using punch was withdrawal cylindrical tissue of $4 \mathrm{~mm}$ diameter throughout its depth, pressing on the marked place (Figure 2).

This cylinder was then inserted into a new block (receiving block), previously prepared with empty bores (Figure 3). The cylinders of several cases were successively added to the receiving block and the position of each sample was identified in spreadsheet with column and row references ( $X$ and $Y$ axes). At the end, it was achieved a receiver block with 10 different samples. This block had sequential histological sections numbered slides treated with adhesive that allowed carrying out multiple reactions ${ }^{4}$.
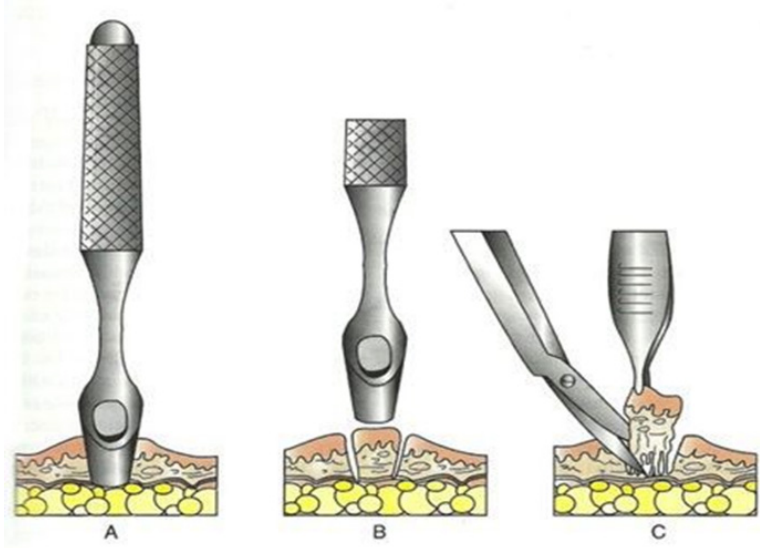

Figure 2-Removal of cylindrical tissue after session with punch.

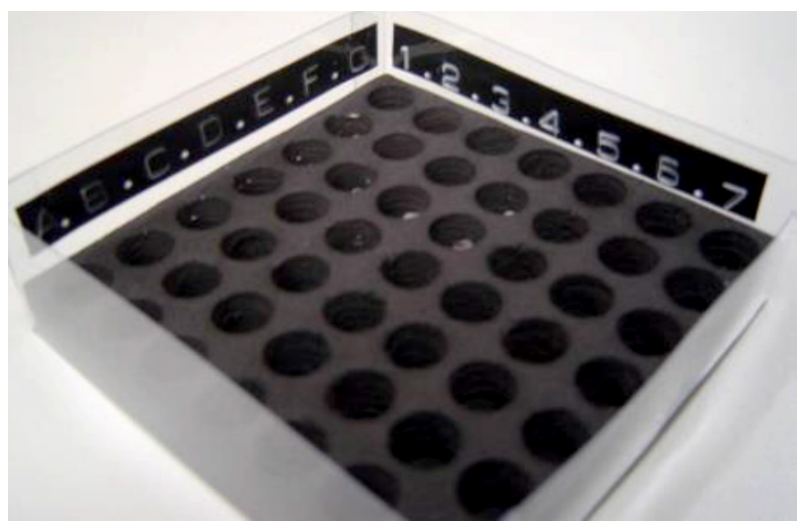

Figure 3 - Block receiver mounted with their identifications as map.

In this study, each block corresponding to a sub-group with 10 samples each were identified as: CBS 3, CBS 7, CBS 14 and CBS 21, or UHS 3, UHS 7, UHS 14 and UHS 21 according to programmed death after 3, 7, 14 and 21 days.

The staining was performed by standard immunohistochemical method used for matrix metalloproteinase 9 (MMP-9), conversion factor beta (TGF- $\beta$ ) and alpha smooth muscle actin ( $\alpha$-MLA). The pathologist was unaware of the animal study group.

The immunostained slides were subjected to reading through optical microscope connected to the camcorder Dinoeye and computer image analysis software Image Pro Plus $^{\mathrm{TM}}$ (Maryland, USA). Four images in highpower field were captured (CGA=400x), with total area of $115226,1 \mu^{2}$ and resolution of 1024 x 768 pixels. The positive control reaction was scanned and an CGA image was chosen as a mask, containing the appropriate positive for the selected biomarker (Figure 4).

The area $\mu \mathrm{m}^{2}$ generated by this method was then divided by the constant $115226.1 \mu \mathrm{m}^{2}$ which is the total area of the evaluated field, generating percentage of immunopositive area per CGA. Mean 4 CGA percentages was calculated in each case (Table 1 ). 


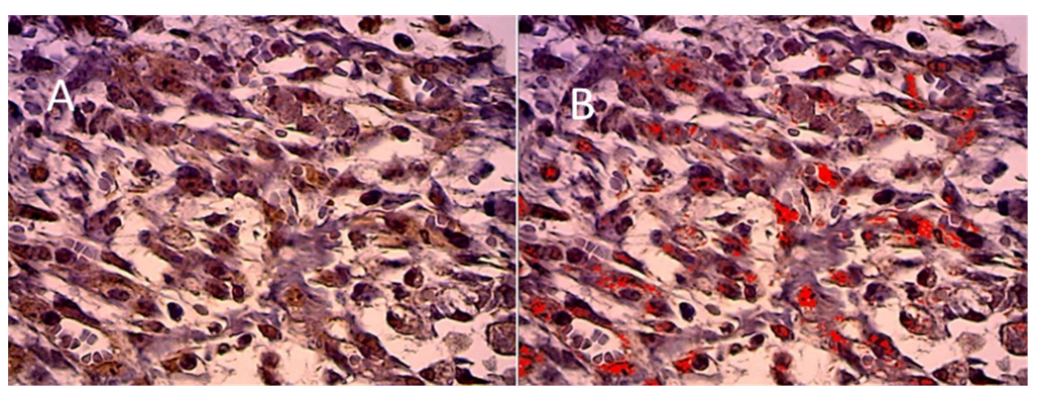

Figure 4 - Immunohistochemistry TGF- $\beta$ CBS 3 subgroup: A) Submitted to immunohistochemical method; B) Immunopositive area in red.

Table 1 - Example of 4 immunopositive areas of each sample, with CBS 3 subgroup medium area of each animal.

\begin{tabular}{|c|c|c|c|c|c|c|c|}
\hline & & & $\mathrm{Mn}$ & & & & \\
\hline & TMA & Photo 1 & Photo 2 & Photo 3 & Photo 4 & $\begin{array}{l}\text { Animal } \\
\text { average }\end{array}$ & $\begin{array}{c}\text { \% Positive } \\
\text { area }\end{array}$ \\
\hline & $1 \mathrm{~A}$ & 2398.8635 & 1634.8127 & 5156.5708 & 3829.6743 & 3254.980325 & $3.32 \%$ \\
\hline CBS & $1 B$ & 7868.6494 & 6753.7031 & 4863.9614 & 4415.334 & 5975.411975 & $5.18 \%$ \\
\hline & $1 C$ & 8057.3438 & 7038.5112 & 2989.8218 & 5314.2085 & 5849.971325 & $5.07 \%$ \\
\hline & 1D & 4967.1401 & 1939.3439 & 1648.2068 & 897.99158 & 2363.170595 & $2.05 \%$ \\
\hline & $2 \mathrm{~A}$ & 2074.0205 & 1570.3446 & 4280.2153 & 1444.4991 & 2342.269875 & $2.01 \%$ \\
\hline & $2 B$ & 6438.1328 & 8201.7354 & 4433.7324 & 7151.4043 & 6556.251225 & $5.68 \%$ \\
\hline & $2 C$ & 5418.123 & 6656.7065 & 5387.8022 & 6749.729 & 6053.090175 & $5.25 \%$ \\
\hline & $2 \mathrm{D}$ & 9160.8096 & 3207.6594 & 7015.8442 & 6408.4014 & 6448.17865 & $5.59 \%$ \\
\hline & $3 \mathrm{~A}$ & 3446.9866 & 4144.0669 & 4818.0391 & 2552.969 & 3740.51540 & $3.24 \%$ \\
\hline & $3 B$ & 4081.9539 & 2637.6018 & 6509.9604 & 6032.9258 & 4815.610475 & $4.17 \%$ \\
\hline & $\begin{array}{l}\text { General } \\
\text { average }\end{array}$ & & & & & 4739.945002 & $4.11 \%$ \\
\hline
\end{tabular}

\section{Picrosirus red method}

Collagen analysis was made by Sirius Red technique and examining them under polarized light. The collagen type III fibers, thinner and dispersed under polarized light, are weakly birefringent and acquire shades ranging from yellow to green, while the type I, thicker and highly birefringent, shades ranging from orange to red.

The slides were examined without established identification, with the same equipment and facilities cited for immunostaining. Initially, the slide image was taken by computer, and with the help of the
Image Pro-Plus was selected a photomicrograph that serialized, as mask, the measuring the interest areas. With the eyedropper tool in photomicrograph identified as a mask, the colors of interest were selected (shades ranging from yellow to green to collagen type III and ranging from orange to red to collagen type I) and the program automatically identified collagens I and III for its color under polarized light by highlighting them in photomicrograph. This mask containing the color selection was superimposed on all other photomicrographs, automatically identifying the areas of collagen I and III. Since the total area of examination 
was constant, the program supplied the area and the percentage of it in the study object, namely type I and III collagen. Were measured three photomicrographs ( $x 20$ objective lens) per histologic section on each slide, yielding, so, the average of the reading section.

\section{Statistical analysis}

Quantitative variables were described by the mean and standard deviation statistics. For comparison of the types of scalpel in each time, was used Student $t$ test for independent samples; for comparison two moments together, it was considered the Student t test for independent samples, considering the model analysis of variance as source of variation to estimate the variance within moments of evaluation. To maintain the overall level of significance was considered the Bonferroni procedure. To assess the normalcy of variables, within each type of scalpel and each time was used Jarque-Bera test. In case of rejection of normality hypothesis was investigated data transformation to meet that condition. To compare the times within each group, in relation to the classification hematoma, dehiscence and compliance, it was considered the chisquare test. To compare the groups at each time, with respect to adherence classification was used Fisher's exact test. For the analysis of variance on the type of collagen and its concentration was used the nonparametric Mann-Whitney. $p$ values less than 0.05 were considered statistically significant. Data were analyzed with the computer program IBM SPSS v. 20

\section{- Results}

\section{Macroscopic evaluation}

No deaths were recorded. One animal CBS3 subgroup had hematoma without statistical significance $(p=1)$. Two others UHS 3 subgroup had infection and dehiscence in suture line observed after their death, without statistical significance $(p=1)$. In relation to adhesions, they were observed only in intensity 1 (Table 2). No fistulae were observed.

Statistical analysis on the CBS $(p=1)$ and UHS ( $p=0.595)$ groups showed no significant difference between them.

Table 2 - Adhesions classified by grade and observation periods.

\begin{tabular}{ccccccccc} 
Adhesion & CBS 3 & UHS 3 & CBS 7 & UHS 7 & CBS14 & UHS 14 & CBS21 & UHS 21 \\
\hline Grade 0 & 9 & 9 & 9 & 7 & 9 & 8 & 10 & 9 \\
Grade 1 & 1 & 1 & 1 & 3 & 1 & 2 & 0 & 1 \\
$\begin{array}{c}\text { Grade2 } \\
\text { Grade 3 }\end{array}$ & & & & & & & & \\
Total & 10 & 10 & 10 & 10 & 10 & 10 & 10 & 10 \\
\hline
\end{tabular}

\section{Microscopic analysis}

\section{$\underline{\text { Immunohistochemistry }}$}

Matrix metalloproteinase 9 (MMP9) expression of MMP-9 in CBS follow-up, a progressive increase in its concentration, more evident from 7 to 14 days, with less progression to 21 . In the series where were used UHS, $3^{\text {rd }}$ day already had high levels, up to the $7^{\text {th }}$ day and decreased to $14^{\text {th }}$ and the level was maintained until day 21. Statistical analysis of MMP-9 expression in the comparison of the two scalpel types were significant at the $3^{\text {rd }}, 7^{\text {th }}$ and $21^{\text {th }}$ days (Table 3 and Figure 5).

The expression of MMP-9 was observed in all cases (Figure 6) varying the tissue immunostaining between $2.65 \%$ and $11.50 \%$. 
Table 3 - MMP-9, TGF- $\beta$ and $\alpha-A M L$ (expressed as mean+SD) for CGA and statistical analysis in cold and harmonic scalpels.

\begin{tabular}{|c|c|c|c|c|c|}
\hline \multirow{2}{*}{ Scalpel } & & \multicolumn{4}{|c|}{ Subgroups } \\
\hline & & 3 days & 7 days & 14 days & 21 days \\
\hline \multirow{3}{*}{ Cold blade } & MMP-9 & $4.739 .95 \pm 1.676 .9$ & $6.633 .82 \pm 1.867 .31$ & $10.560 .1 \pm 1.653 .4$ & $11.533 .89 \pm 1.161 .7$ \\
\hline & TGF- $\beta$ & $1.878 .74 \pm 1.496 .4$ & $636.02 \pm 879.69$ & $1.172 .74 \pm 633.35$ & $1.078 .6 \pm 556.78$ \\
\hline & $\alpha-A M L$ & $1.836 .81 \pm 724.47$ & 2.011.21 \pm 516.91 & $1.879 .22 \pm 721.32$ & $2.022 .17 \pm 1.007 .34$ \\
\hline \multirow{3}{*}{$\begin{array}{l}\text { Harmonic } \\
\text { ultrassonic }\end{array}$} & MMP-9 & $9.185 .9 \pm 1.502 .61$ & $12.036 .44 \pm 1.216 .7$ & $9.104 .05 \pm 2.201 .6$ & $9.171 .86 \pm 1.785 .63$ \\
\hline & TGF- $\beta$ & $946.69 \pm 638.38$ & $744.66 \pm 1.099 .5$ & $547.56 \pm 1.006 .31$ & $195.11 \pm 157.31$ \\
\hline & $\alpha-A M L$ & $1.975 .41 \pm 653.38$ & $2.450 .35 \pm 773.47$ & $2.832 .99 \pm 893.45$ & $2.741 .54 \pm 699.27$ \\
\hline \multirow{3}{*}{$p$ value* } & MMP-9 & $<0.001$ & $<0.001$ & 0.099 & 0.001 \\
\hline & TGF- $\beta$ & 0.081 & 0.826 & 0.010 & $<0.001$ \\
\hline & $\alpha-A M L$ & 0.665 & 0.140 & 0.011 & 0.091 \\
\hline
\end{tabular}

*Student $t$ test for independent samples; $(p<0.05)$.

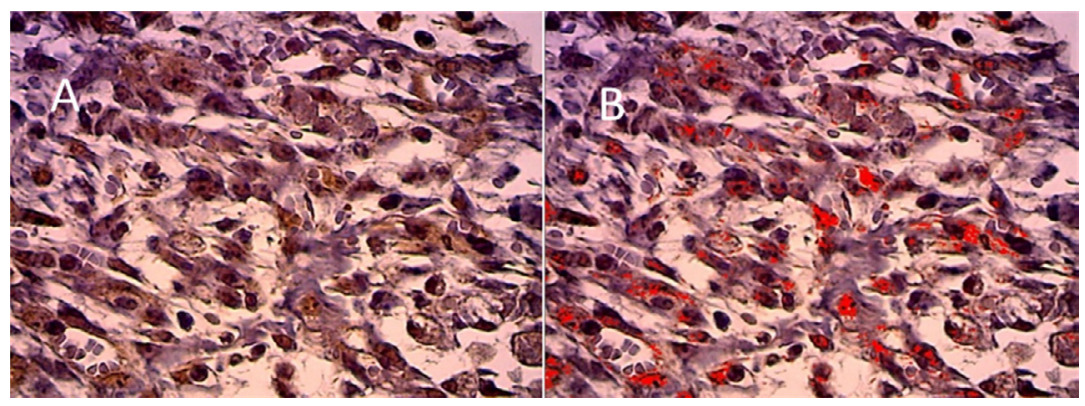

Figure 5 - Average of immune tissue expression (in square micrometers per CGA) of MMP-9 in relation to the CBS and UHS groups at $3^{\text {rd }}, 7^{\text {th }}, 14^{\text {th }}$ and $21^{\text {st }}$ days.

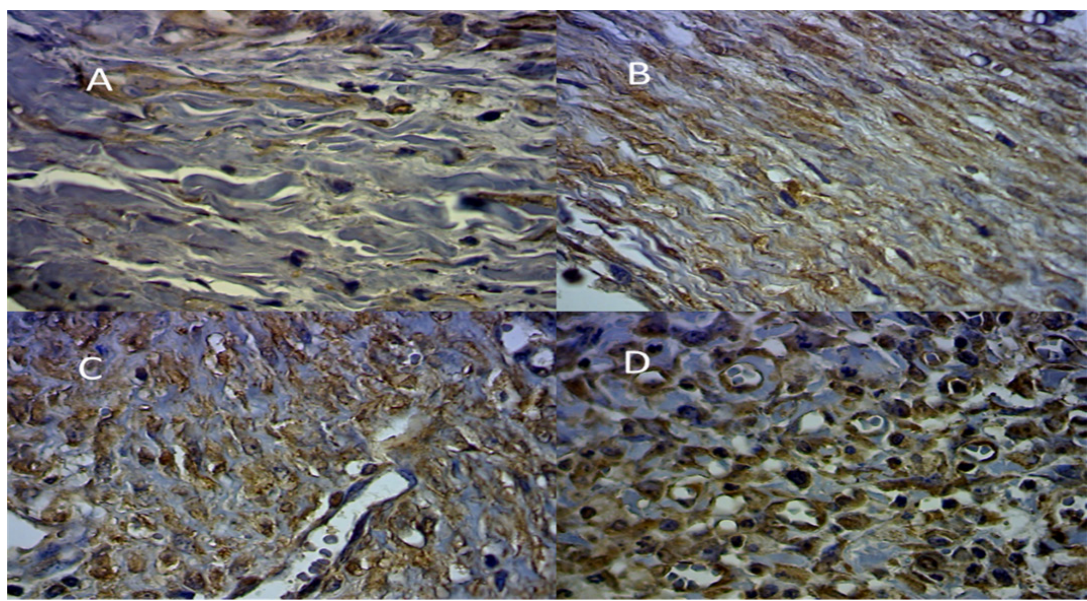

Figure 6- Average area of immunostaining histological samples with MMP-9 (x200): A) 2.65\% CBS 3; B) $4.20 \%$ UHS14; C) $8.84 \%$ UHS 21; D) $11.50 \%$ UHS 7. 
Transformation growth factor-beta (TGF- $\beta$ )

TGF- $\beta$ in incision with cold blade got highest level at the $3^{\text {rd }}$ day, falling down on the $7^{\text {th }}$, going up on $14^{\text {th }}$, with a slight drop to $21^{\text {st }}$ day. In the series where the incision with UHS was held, it was higher after 3 days, with progressive decline in 7, 14 and 21 days.
Statistical analysis comparing the two scalpel types with TGF- $\beta$ expression found statistic significance at 14 and 21 days (Table 3 and Figure 7).

The expression of TNF- $\beta$ was observed in all cases varying the tissue immunostaining between $0.03 \%$ and $2.92 \%$ (Figure 9).

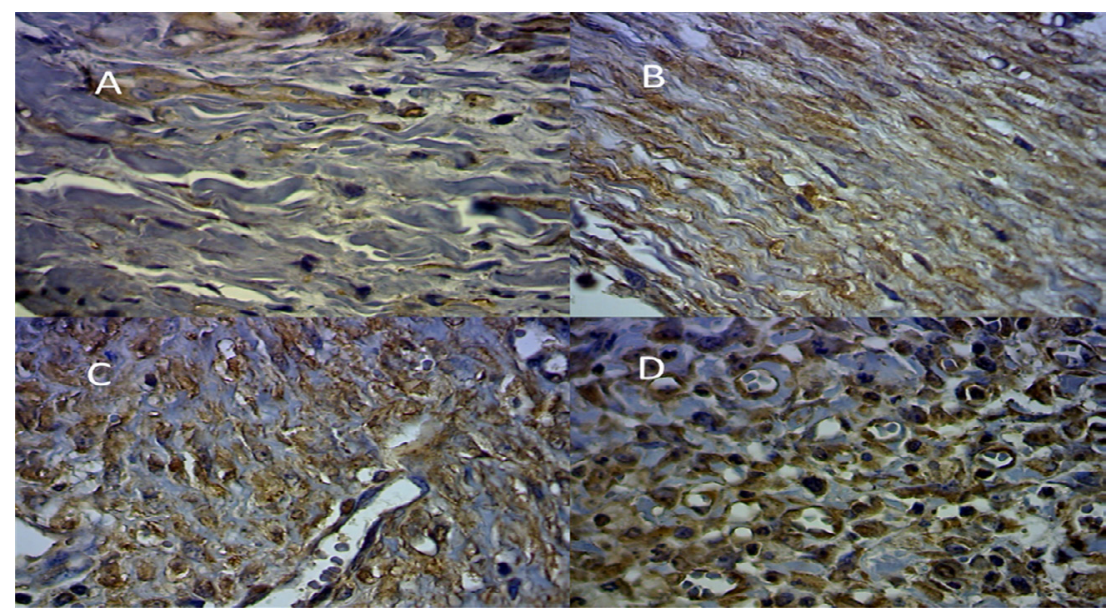

Figure 7 - Average tissue immunostaining (in square micrometers per CGA) of TGF- $\beta$ in relation to the CBS and UHS groups, on the $3^{\text {rd }}, 7^{\text {th }}, 14^{\text {th }}$ and $21^{\text {st }}$ days.

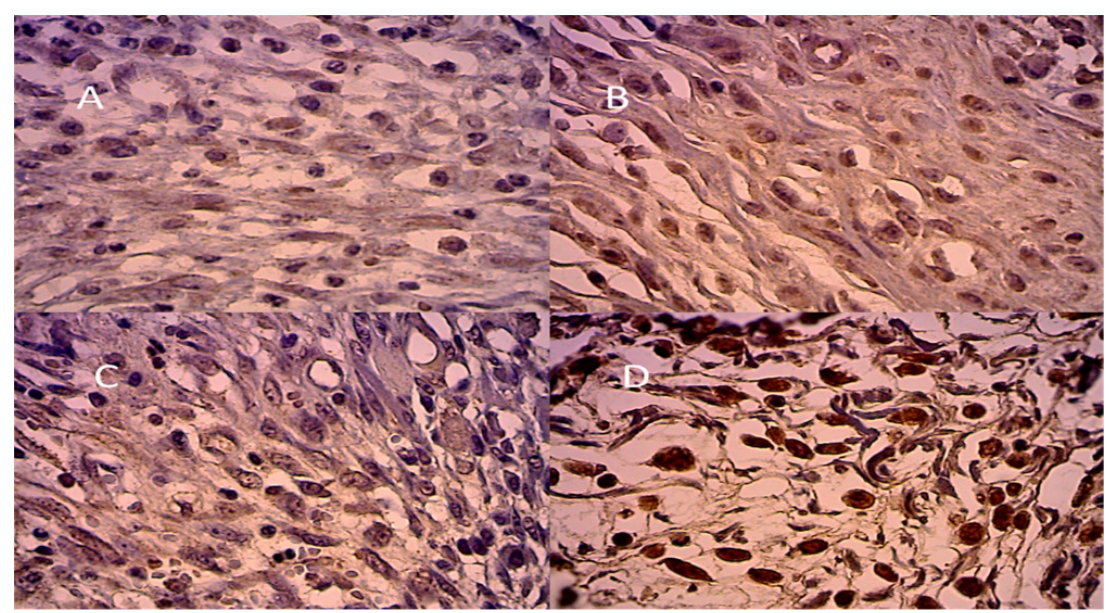

Figura 8 - Average area of immunostaining histological samples with TGF $\beta$ (x200): A) $0.08 \%$ CBS 14 ; B) $0.64 \%$ UHS 7; C) $1.85 \%$ CBS 3; D) $2.92 \%$ CBS 3.

\section{Alpha smooth muscle actin ( $\alpha$-AML)}

$\alpha$-AML expression showed levels slightly variable in the series where incision with CBS was carried out, with a slight increase from $3^{\text {rd }}$ to $7^{\text {th }}$ days, discreet decrease from $7^{\text {th }}$ to $14^{\text {th }}$ days and a slight increase up to $21^{\text {st }}$, but remained constant. When using UHS, there was increase from $3^{\text {rd to } 7 \text { th }}$ days, repeated from $7^{\text {th }}$ to $14^{\text {th }}$ day, and slight decrease after 21 days.

$\alpha$-AML statistical analysis comparing the two scalpel types after 14 days is seen in Table 3 and Figure 9.

$\alpha$-AML expression was observed in all cases (Figure 10) varying the tissue immunostaining between $0.88 \%$ and $3.23 \%$. 


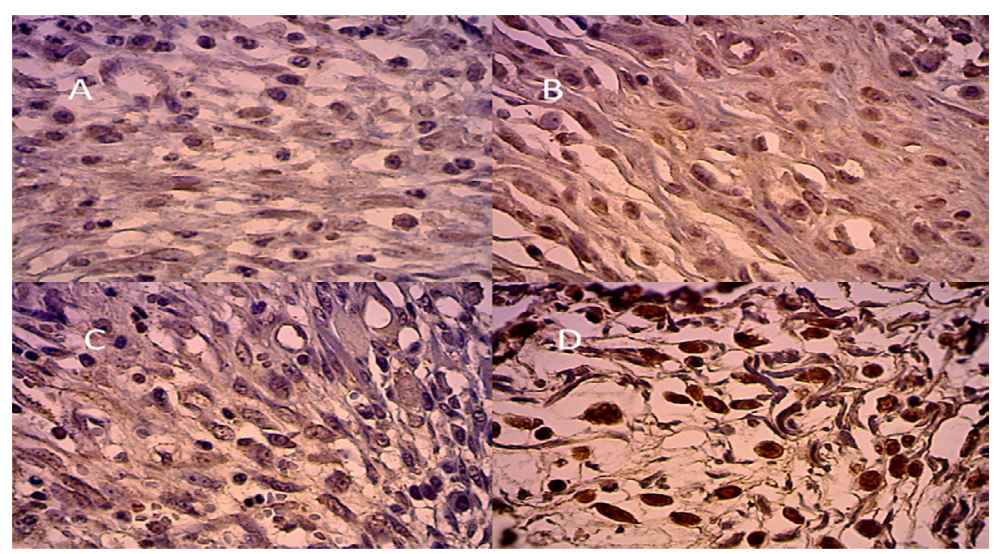

Figure 9 - $\alpha$-AML average tissue immunostaining (in square micrometers per CGA) of in relation to CBS and UHS groups on the $3^{\text {rd }}, 7^{\text {th }}, 14^{\text {th }}$ and 21 days.

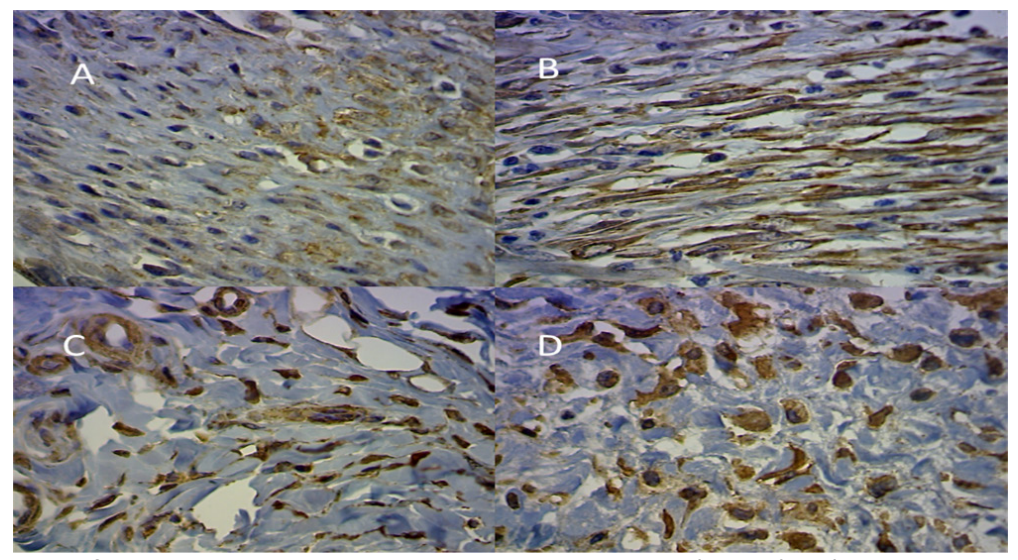

Figure 10 - Average area of immunostaining samples with $\alpha$-AML (x200): A) $1.39 \%$ CBS 21; B) $1.45 \%$ CBS 7; C) $2.04 \%$ CBS 14; D) $3.23 \%$ UHS 3.

\section{Picrosirius color red}

Collagen dosage analysis showed that the mature type I, showed no statistic significant variation in the samples; the immature collagen type III, on the $3^{\text {rd }}$ day was higher in UHS group; on the $7^{\text {th }}$ day was higher in the CBS group; in $14^{\text {th }}$ was equivalent in both groups; and on $21^{\text {st }}$ day the deposit was higher in the group UHS. As a general score, there was higher deposition of collagen type III in UHS group than in the CBS with $\mathrm{p}<0.001$ or $0.01 \%$, with statistical significance (Figure 11).

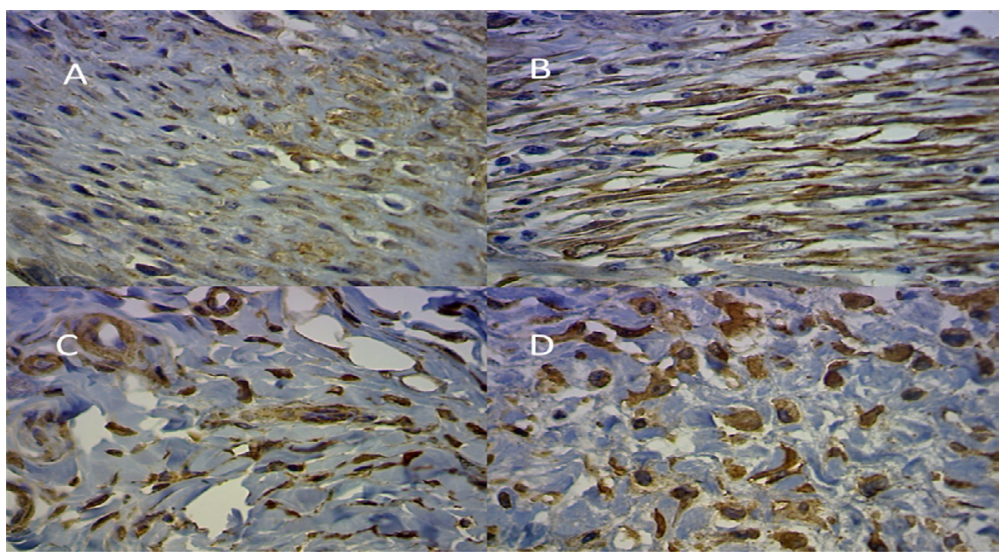

Figure 11 - Quantification of mature (type I) and immature (type III) collagen in both groups. 


\section{- Discussion}

Dieresis and synthesis are routine surgical procedures and the proper understanding of the healing process is of great importance, since disturbances in the normal healing course can pose severe clinical problem with morbidity and mortality ${ }^{5-8}$.

The objective of increasing the safety and quality of a surgical procedure aimed in time reduction and complications. New tools were created, as electrocautery, laser radiation, cryosurgery and currently the harmonic scalpel.

The UHS is being used over 15 years in various surgical specialties with advantages. It was here applied because less energy is transduced to tissue compared to other devices, and do not pass electricity through the body,9. Another benefit is reduction in analgesics administration in the postoperative period $^{10-15}$

CBS is the most used in surgical incisions despite bleeding, need for sutures and other disadvantages, but still promotes less trauma to adjacent tissues ${ }^{16}$. This statement was also confirmed in this study. Other authors argue that conventional scalpel produces leakage of blood and lymph causing greater swelling and scarring ${ }^{11,17-19}$.

A major problem attributed to UHS is the high cost of the equipment. Irfan et al. ${ }^{20}$ believe that all the advantages mentioned about the harmonic scalpel justify the costs. The clash of these conflicting opinions draws attention to the important aspect of cost/ benefit ratio: the level of the surgeon's ability to manipulate the equipment can decrease hospital costs.

Tissue microarray technique (microarray-Tma tissue)

As the conventional method of analyzing samples one by one is relatively expensive, this technique has been used to reduce costs. It is based on the construction of a paraffin block with cylindrical pieces of tissue samples obtained from tens or hundreds of original paraffin blocks. Thus, the use of immunohistochemistry to know the expression of a particular marker, may occur in a TMA slide with hundreds of samples at the cost of a single reaction ${ }^{21}$.

The TMA compared to conventional methods has: satisfactory assay areas at different shear levels; possibility of experiment repetition; large number of samples simultaneously analyzed; great savings in time; lower costs; and reactions standardization. The fidelity of the results regarding the use of conventional cuts was studied during method validation and is demonstrated in several papers in the literature.

\section{Microscopy analysis}

Costa Filho $^{22}$ in the same procedure revealed that microscopic examination with hematoxylin-eosin and Gomori trichrome revealed that the cut with UHS delays the healing, has more prolonged inflammatory process, greater tissue necrosis and fibrogenesis delay. Microscopic evaluation proved more intense inflammatory phase in the incisions made by the UHS compared with CBS; this difference was most evident in the $3^{\text {rd }}$ and $7^{\text {th }}$ days, and after 14 days the parameters were similar. Garcia et al. ${ }^{23}$, performing similar experiment, but using electrocautery, found no significant changes in healing in both groups.

The expression of MMP-9 in incision with the CBS, showed a progressive increase in concentration, more evident from $7^{\text {th }}$ to $14^{\text {th }}$ days, and less in $21^{\text {st }}$. In the group where was used UHS, on the $3^{\text {rd }}$ day had higher MMP9 up until the $7^{\text {th }}$ day, decreasing on $14^{\text {th }}$ and maintained until $21^{\text {th }}$ day, as expected. The presence of MMP-9 throughout the study 
period, showed high inflammatory phase in remodeling process, more intense and prolonged in $\mathrm{UHS}^{22}$.

Navarro et al. ${ }^{24}$ reported that MMP-9 participates in many physiological processes in the human metabolism, also involved in pathological processes such as tissue destruction. Perches et al. ${ }^{25}$ said that MMPs may be observed in any inflamed tissue and cell cultures varying according to the disease, since every tissue has extracellular matrix needing MMPs to tissue remodeling. Oliveira ${ }^{26}$, in liver healing, demonstrated the importance of TGF- $\beta$ in the fibrogenesis process in combination to levels in collagen type I.

Martinez $^{27}$ in dental pulp cells and human gingival obtained results showing that TGF- $\beta 1$ induces $\alpha$-AML expression suggesting myofibroblastic stimulation, which was not confirmed in this study.

The $\alpha$-AML expression levels showed be more constant in the series where incision with cold blade was performed. In UHS group wound remodeling was more intense.

The simplest method for quantification of collagen is the use of the dye Sirius Red F3BA $^{28}$. Collagen types I, II, III discloses various colors and intensities of birefringence in the same histological section. This is due to the fact that different interstitial collagens show different patterns of physical aggregation. The type I has thick collagen fibers composed of fibrils densely packed and therefore exhibits birefringence active in yellow or reddish. The type III comprises fine reticular fibers, composed of fine fibrils, loosely arranged presenting weak greenish birefringence. The fiber with green color, compatible with type III collagen, is predominant in the initial period declining in later ones. Already, thick and red fibers, compatible with type I collagen, have opposite behavior. In this study there was predominance of collagen type III in UHS compared with CBS.

\section{Conclusions}

The use of cold blade performed better than the harmonic ultrasonic scalpel in healing process of abdominal aponeurosis in rats. The ultrasonic showed greater lesion area at the time of incision that promoted delay on regeneration and maturation of the scar.

\section{References}

1. Vore SJ, Wooden WA, Bradfield JF, Aycock ED, Vore PL, Lalikos JF, Hudson SS. Comparative healing of surgical incisions created by a standard "bovie," the Utah Medical Epitome Electrode, and a Bard-Parker cold scalpel blade in a porcine model: a pilot study. Ann Plast Surg. 2002 Dec;49(6):635-45. PMID: 12461448.

2. Coutinho TR, Malafaia O, Torres OJ, Ribas Filho JM, Kaminski AF, Cella IF, Jurkonis LB. Comparison between electrocautery and fibrin selant after hepatectomy in rats. Rev Col Bras Cir. 2014 May-Jun;41(3):198-202. PMID: 25140652.

3. Franconi F, Roux J, Lefebvre-Lacoeuille C, Lemaire $\mathrm{L}$. Imaging visceral adhesion to polymeric mesh using pneumoperitonealMRI in an experimental rat model. Surg Endosc. 2015 Jun;29(6):1567-73. doi: 10.1007/s00464-014-3843-9.

4. Serigiolle LC, Barbieri RL, Gomes HM, Rodrigues DA, Studart SV, Leme PL.Critical analysis of experimental model for study of adhesions after incisional hernias induced in rats' and repair of abdominal wall with different biomaterials. Arq Bras Cir Dig. 2015 Jul-Sep;28(3):178-82. doi: 10.1590/ S0102-67202015000300008.

5. Gonçalves RO, de Moraes e Silva E, Lopes Filho GJ. Immunohistochemical evaluation of fibrillar components of the extracellular matrix of transversalis fascia and anterior abdominal rectus sheath in men with inguinal hernia. Rev Col Bras Cir. 2014 JanFeb;41(1):23-9. PMID: 24770770.

6. Askarpour S, Peyvasteh M, Sherafatmand S. Comparison between inguinal herniotomies with and without incising external oblique aponeurosis: a randomized clinical trial. Arq Bras Cir Dig. 2017 Jul-Sep;30(3):187-9. doi: 
10.1590/0102-6720201700030006.

7. Pedroso LM, DE-Melo RM, DA-Silva NJ Jr. Comparative study of postoperative pain between the lichtenstein and laparoscopy surgical techniques for the treatment of unilateral primary inguinal hernia. Arq Bras Cir Dig. 2017 Jul-Sep;30(3):173-6. doi: 10.1590/0102-6720201700030003.

8. Utrabo CAL, Czeczko NG, Busato CR, Montemór-Netto MR, Lipinski L, Malafaia $\mathrm{O}$. Tensiometric analysis of meshes used in abdominal ventral wall defects in rats. Arq Bras Cir Dig. 2017 Jul-Sep;30(3):165-8. doi: 10.1590/0102-6720201700030001.

9. Godinho M, Padim P, Evora PR, Scarpelini $S$. Curbing Inflammation in hemorrhagic trauma: a review. Rev Col Bras Cir. 2015 Jul-Aug;42(4):273-8. doi: 10.1590/010069912015004013.

10.Liao G, Wen S, Xie X, Wu Q. Harmonic scalpel versus monopolar electrocauterization in cholecystectomy. JSLS. 2016 JulSep;20(3). pii: e2016.00037. doi: 10.4293/ JSLS.2016.00037.

11.De Palma $M$, Rosato $L$, Zingone $F$, Orlando G, Antonino A, Vitale M, Puzziello A. Postthyroidectomy complications. The role of the device: bipolar vs ultrasonic device: Collection of data from 1,846 consecutive patients undergoing thyroidectomy. Am J Surg. 2016 Jul;212(1):116-21. doi: 10.1016/j. amjsurg.2015.05.024

12.de Oliveira RP, Portari Filho PE, Iglesias AC, de Oliveira CA, Pannain VL. Comparative study of the different degrees of risk of gastrointestinal stromal tumor. Rev Col Bras Cir. 2015 Jan-Feb;42(1):32-6. doi: 10.1590/0100-69912015001007.

13.Magalhães CR, Malafaia $O$, Torres OJ, Moreira LB, Tefil SC, Pinherio Mda R, Harada $B A$. Liver regeneration with I-glutamine supplemented diet: experimental study in rats. Rev Col Bras Cir. 2014 MarApr;41(2):117-21. PMID: 24918725.

14.Dean A, Alamillos F, Centella I, García-Álvarez S. Neck dissection with theharmonic scalpel in patients with squamous cell carcinoma of the oral cavity. J Craniomaxillofac Surg. 2014 Jan;42(1):84-7. doi: 10.1016/j. jcms.2013.02.007.

15.Pais-Costa SR, Farah JF, Artigiani-Neto R, Martins SJ, Goldenberg A. Evaluation of P53, E-cadherin, Cox-2, and EGFR protein immunoexpression on prognostic of resected gallbladder carcinoma. Arq Bras Cir Dig. 2014 Apr-Jun;27(2):126-32. PMID: 25004291.

16. Morosolli AR, Veeck EB, Niccoli-Filho W, Gomes MF, das Graças VGM. Healing process after surgical treatment with scalpel, electrocautery and laser radiation: histomorphologic and histomorphometric analysis. Lasers Med Sci. 2010 Jan;25(1):93100. doi: 10.1007/s10103-009-0674-3.

17. Kagueyama FM, Nicoli FM, Bonatto MW, Orso IR. Importance of biopsies and histological evaluation in patients with chronic diarrhea and normal colonoscopies. Arq Bras Cir Dig. 2014 Jul-Sep;27(3):184-7. PMID: 25184768.

18. Alexiou VG, Salazar-Salvia MS, Jervis PN, Falagas ME. Modern technologyassisted vs conventional tonsillectomy: a meta-analysis of randomized controlled trials. Arch Otolaryngol Head Neck Surg. 2011 Jun;137(6):558-70. doi: 10.1001/ archoto.2011.93.

19.Ismail A, Abushouk Al, Elmaraezy A, Menshawy $A$, Menshawy $E$, Ismail M, Samir E, Khaled A, Zakarya H, El-Tonoby A, Ghanem E. Cutting electrocautery versus scalpel for surgical incisions: a systematic review and meta-analysis. J Surg Res. 2017 Dec;220:14763. doi: 10.1016/j.jss.2017.06.093.

20.Huang J, Yu Y, Wei C, Qin Q, Mo Q, Yang W. Harmonic scalpel versus electrocautery dissection in modified radical mastectomy for breast cancer: a meta-analysis. PLoS One. 2015 Nov 6;10(11):e0142271. doi: 10.1371/journal.pone.0142271.

21.Chen XL, Chen XZ, Lu ZH, Wang L, Yang $K$, $\mathrm{Hu}$ JK, Zhang B, Chen ZX, Chen JP, Zhou ZG. Comparison of ultrasonic scalpel versus conventional techniques in open gastrectomy for gastric carcinoma patients: a systematic review and meta-analysis. PLoS One. 2014 Jul 31;9(7):e103330. doi: 10.1371/journal.pone.0103330.

22.Costa Filho,OAA. Cicatrização da aponeurose da parede abdominal de ratos após incisão com bisturi de lâmina fria e bisturi harmônico ultrasônico (Dissertação). Instituto de Pesquisas Médicas, Faculdade Evangélica do Paraná; 2012.

23.Garcia A, Nascimento JE, Darold EM, Pimentel RE, Curvo EA, Daud FO. Healing 
of abdominal wall aponeurosis of rats after incision with either cold scalpel or electrocautery. Acta Cir Bras. 2007 MarApr;22 Suppl 1:12-5. PMID: 17505649.

24.Navarro VP; Nelson-Filho $P$, Silva LAB, Freitas AC. The participation of matrix metalloproteinases in the physiopathological processes of the oral cavity. Rev Odontol UNESP. 2006;35(4): 233-8.

25.Perches CS, Brandão CVS, Ranzani JJT, Rocha NR, Sereno M, Fonzar JF. Matriz metaloproteinases na reparação corneal. Revisão de literatura. Vet Zootec. 2012;19(4):480-9.

26.Oliveira FS. A contribuição do fator transformador de crescimento beta 1-TGF $\beta 1$ na fibrose hepática: estudos in vivo e in vitro. 2009. Pós graduação em saúde da criança e do adolescente. Universidade Federal do Rio Grande do Sul.

27. Martinez EF. Estudo da expressão da a-actina de músculo liso em cultura de células de polpas dentárias e gengivas humanas tratadas com o fator de transformação de crescimento- $\beta 1$ (TGF- $\beta 1$ ) (Dissertação). Faculdade de Odontologia, Universidade de São Paulo; 2008.

28.Constantine VS, Mowry RW. Selective staining of human dermal collagen. II. The use of picrosirius red F3BA with polarization microscopy. J Invest Dermatol. 1968 May;50(5):419-23. PMID: 4172462.

\section{Correspondence:}

Octavio Antonio Azevedo da Costa-Filho

Rua Prudente de Moares, 321

84040-150 Ponta Grossa - PR Brasil

Tel.: (55 41)99113-7351

octaviocostafilho@gmail.com

Received: May 22, 2018

Review: July 20, 2018

Accepted: Aug 18, 2018
Conflict of interest: none

Financial source: CAPES

${ }^{1}$ Research performed at Instituto de Pesquisas Médicas (IPEM), Faculdade Evangélica do Paraná (FEPAR), Curitiba - PR, Brazil. Part of PhD degree thesis, Postgraduate Program in Principles of Surgery, FEPAR. Tutor: Prof. Dr. Jurandir Marcondes Ribas-Filho. 